\title{
Lavandin Oil
}

National Cancer Institute

\section{Source}

National Cancer Institute. Lavandin Oil. NCI Thesaurus. Code C72192.

The essential oil extracted from the flowering tops of Lavandula $\mathrm{x}$ intermedia. Lavandin oil has expectorant properties and is used for the treatment of respiratory illnesses. 